16. Pepall, L. M., \& Richards, D. J. (2002). The Simple Economics of Brand Stretching. The Journal of Business, 75(3), 535-552 [in English].

17. Pitta, D. A. \& Katsanis, L. P. (1995). Understanding brand equity for successful brand extension. Journal of Consumer Marketing, 12(4), 51-64 [in English].

18. Ries Al., \& Trout, J. (1993). The 22 immutable laws of marketing: violate them at your own risk. 1st ed. New York : Harper Business, 143 p. [in English].

19. Ries, Al., \& Ries, L. (2000-2001). The 22 Immutable Laws of Branding. Symphonya. Emerging Issues in Management, 1, 30-34 [in English].

\title{
Yunyk I. D. The specifics of development management of university professor's brand
}

The article considers the specifics of development management of a university professor's brand, which is the key to competitiveness of a specialist in the market of educational and research services on a national and global scale. The three-vector orientation of the strategy of expanding the university professor's brand is substantiated there. The interval-territorial determinants of ensuring the effectiveness of the implementation of this strategy are highlighted. It is emphasized that unjustifiably intensified application of this strategy leads to the weakening of personal brand due to lack of resources needed to achieve the "branding" goal, and late application of this strategy leads to loss of the brand owner an opportunity to realize his personally-professional potential. Emphasis is also placed on the inexpediency of long-term disregard by specialist the need to expand their own brand, as it is naturally interpreted by the target audience as a sign of its transition to a stage of stagnation and further decline. Author outlines risks associated with the erosion of personal brand identity due to its uncontrolled expansion in a highly competitive market of educational and research services. The inadmissibility of the application of the strategy of expanding one's own brand as a destructively oriented tool of preventive competition with competing university professors' brands has been proved. The functional inefficiency of application of the strategy of brand stretching by the university specialist's is argued. It is proposed to use the specifics of perception by target audience the information about university professor's brand as the main criterion for differentiation of strategies of its expansion and expansion.

Key words: brand, branding, professor, university, management, strategy of extension, strategy of stretching, personally-professional potential.

\author{
УДК 378.14.015.62 \\ DOI https://doi.org/10.31392/NPU-nc.series5.2021.83.49
}

Яценко В. В.

\section{ПЕДАГОГІЧНА МАЙСТЕРНІСТЬ ВИКЛАДАННЯ \\ ПСИХОЛОГО-ПЕДАГОГІЧНИХ ДИСЦИПЛІН ЗДОБУВАЧАМ ОСВІТИ НА СУЧАСНОМУ ЕТАПІ}

Висвітлено сутність поняття “педагогічна майстерність”. Визначено особливості викладання психолого-педагогічного дисциплін у контексті формування професійного самовизначення здобувачів спеціальності 012 "Дошкільна освіта”, зокрема її когнітивно-гностичного компоненту. Встановлено, щзо у процесі інтеграційного викладання психолого-педагогічних дисциплін із урахуванням індивідуально-психологічних особливостей особистості здобувача йде иілеспрямований процес поглиблення $i$ зміцнення його знань про сутність діяльності педагога-вихователя. Наведено чотири відносно самостійні, але взаємопов 'язані блоків педагогічної майстерності: психолого-педагогічні знання; особистісні та професійно значущі якості; педагогічні здібності; навички й уміння будувати освітній процес, мистецтво здійснення педагогічної діяльності. Зауважено, щзо досвід роботи передових ЗВО у сфері підготовки майбутніх фахівиів дошкільної освіти дозволяе виділити у структурі педагогічної майстерності викладання психолого-педагогічних дисциплін такі взаємопов'язані елементи: гуманістичну спрямованість, професійні знання, базові педагогічні здібності, педагогічну техніку. Виокремлено, що педагогічні здібності за своєю суттю виступають індивідуальною траєкторією розвитку педагогічного працівника. Виділено три основні періоди процесу формування педагогічної майстерності: період становлення викладачів-початківиів; удосконалення педагогічної майстерності у процесі набуття досвіду; педагогічне новаторство. Відзначено, щчо досвід викладання психологічних і педагогічних дисииплін для здобувачів дошкільної освіти підтверджує необхідність використання механізму реалізаиії інновачійної освітньої діяльності на основі інтерактивних методів навчання з метою вирішення проблемних завдань підготовки майбутнього фахівия (таких як полілог, навчально-педагогічний тренінг, імітаційно-рольове моделювання, педагогічна майстерня). Запропоновано напрями удосконалення педагогічної майстерності викладання психолого-педагогічних дисциплін здобувачам дошкільної освіти: ичілісність і безперервність підготовки та підвищення кваліфікації педагогічних працівників; формування у викладачів стійкої мотивації до вдосконалення педагогічної майстерності; вдосконалення педагогічної техніки.

Ключові слова: освіта, викладач, здобувачі дошкільної освіти, педагогічна майстерність, партнерська взаємодія, наставництво, інтерактивні методи навчання, педагогічна майстерня.

На тлі активних інноваційних процесів, що відбуваються в усіх сферах життя сучасної України, стає особливо помітним посилення уваги суспільства до проблем освіти, підвищення їі якості та значимості для різних вікових груп. Насамперед це стосується педагогічної освіти, яку оголошено пріоритетним напрямом 
модернізації вітчизняної освіти загалом. Саме педагогічна освіта має забезпечити формування професійно компетентної особистості педагога, здатного самостійно і творчо вирішувати професійні завдання, усвідомлювати особистісну і суспільну значимість педагогічної діяльності, нести відповідальність за їі результати, сприяти соціальній стабільності та розвитку суспільства. Тому сьогодні найбільш гостро відчувається потреба у підвищенні й ефективності підготовки педагогічних кадрів у ЗВО. Підготовка фахівців у сфері дошкільної освіти здійснюється у ЗВО з урахуванням унікальності періоду дошкільного віку та завдань, котрі стоять перед дошкільною освітою й усією системою освіти України на сучасному етапі. Необхідність акцентувати увагу на підготовці здобувача дошкільної освіти пов’язана 3 тим, що саме у ЗВО здійснюють практико-орієнтовану підготовку фахівців до безпосередньої роботи 3 дітьми.

Вимоги до знань, умінь, дій і особистісних якостей майбутніх вихователів закладів дошкільної освіти чітко сформульовані у Стандарті вищої освіти України підготовки здобувачів другого рівня вищої освіти магістра - з галузі знань 01 “Освіта” спеціальності 012 “Дошкільна освіта”. Як зазначено у Стандарті, магістрант у галузі дошкільної освіти має оволодіти поглибленими теоретичними та практичними знаннями, гнучкими уміннями та сталими професійними навичками, а також додатковою спеціальністю або спеціалізацією задля здійснення управлінської, адміністративної, моніторингової, психологічної діяльності. Виходячи з вимог Стандарту до кадрових умов реалізації основної загальноосвітньої програми дошкільної освіти випускник повинен оволодіти основними компетентностями, необхідними для створення умов повноцінного розвитку дітей: інтегральною (здатністю компетентно розв'язувати складні задачі та проблеми в організації та моніторингу освітнього процесу в системі дошкільної освіти або у процесі навчання фахівців із дошкільної освіти у закладах вищої освіти, що передбачає проведення досліджень, та/або здійснення інновацій у ситуаціях, які характеризуються невизначеністю умов і вимог); загальними (здатністю діяти соціально відповідально та свідомо; здатністю генерувати нові ідеї (креативністю); здатністю працювати у команді, цінувати та поважати різноманітності та мультикультурності; здатністю виявляти, ставити й вирішувати проблеми; здатністю до пошуку, оброблення й аналізу інформації з різних джерел тощо); спеціальними (фаховими, предметними) (здатністю організовувати освітній процес у закладах дошкільної освіти з використанням сучасних засобів, методів, прийомів, технологій; здатністю здійснювати методичний супровід освітньої діяльності закладу дошкільної освіти; здатністю до психолого-педагогічного керівництва особистісним розвитком дітей раннього і дошкільного віку, зокрема дітей з особливими освітніми потребами; готовністю до організації фінансово-господарської діяльності закладів дошкільної освіти; здатністю до самоосвіти, самовдосконалення, самореалізації у професійній діяльності та до конкурентної спроможності на ринку праці; здатністю розробляти та реалізовувати дослідницькі й інноваційні проекти у сфері дошкільної освіти тощо) [14]. У зв'язку із цим особливо актуальним стає питання якісної підготовки майбутніх викладачів до здійснення педагогічної діяльності, адже від науково-педагогічних працівників як одного із компонентів цілісного педагогічного процесу очікується готовність ефективно реалізувати нову парадигму виховання й освіти.

Здійснити підготовку таких кадрів може лише педагог-майстер, тобто фахівець із високою культурою, котрий глибоко володіє своїм предметом. Він також компетентний у відповідних галузях науки і мистецтва, володіє методикою навчання і виховання й високим рівнем майстерності викладання. Таким фахівцем не лише забезпечується свідоме, творче засвоєння знань здобувачами, а й здійснення на них виховного впливу. Тому перевірені педагогічним колективом система і послідовність, високі результати праці викладача, визнання його авторитету здобувачами дошкільної освіти є основними критеріями визначення рівня педагогічної майстерності.

У зарубіжній і вітчизняній психолого-педагогічній літературі проблема формування педагогічної майстерності розглядається як одна з найважливіших у навчанні та професійно-практичній підготовці майбутніх працівників дошкільної освіти. Проблема формування професійної майстерності педагогів висвітлена у працях С. С. Барбіної [1], О. І. Журавльової [12], I. А. Мухіної [10], С. Ф. Поважного [12], Т. I. Туркота [16], О. І. Філіппова [12], М. М. Фіцули [17], які відзначали провідну роль викладача у навчанні та вихованні. Пізніше ці питання у своїх роботах розкрили такі вчені, як І. А. Зязюн [5; 6], Л. В. Крамущенко [6], І. Ф. Кривонос [6], О. Малнацька [8], Н. Мирончук [8], Л. І. Мохнар [9], О. М. Обривкіна [11], М. М. Солдатенко [15], А. І. Харківська [18], О. А. Шолох [19], Є. В. Якимчикас [20] та ін.

Метою статті $є$ дослідження особливостей педагогічної майстерності викладання психолого-педагогічних дисциплін здобувачам освіти на сучасному етапі.

Світовий і вітчизняний досвід свідчить про те, що принципові позитивні зміни в освітній системі неможливі доти, поки не відбувається підвищення якості професійної діяльності педагогічного складу, яке проявляється у їхній педагогічній майстерності.

Існує кілька підходів до визначення педагогічної майстерності та їі структури. Так, дослідниця Є. С. Барбіна розуміє педагогічну майстерність як синтез наукових знань, вмінь і навичок методичного мистецтва й особистих якостей педагога [1, с. 182]. На думку I. А. Зязюна, педагогічна майстерність - це виявлення високого рівня педагогічної діяльності, синтез наукових знань, умінь і навичок методичного мистецтва й особистих якостей педагога, котра забезпечує високий рівень самоорганізації професійної роботи [5, с. 35]. Т. І. Туркот вважає, що педагогічна майстерність - це високе мистецтво навчання 
і виховання, яке постійно вдосконалюється й основу якого становлять професійні знання, вміння та здібності. Педагогічна майстерність грунтується на педагогічних здібностях (дидактичних, організаторських, комунікативних, перцептивних, сугестивних, науково-пізнавальних, прогностичних, дослідницьких), а також на емоційній стійкості та здатності до педагогічної імпровізації [16, с. 463-464]. 3 погляду М. М. Фіцули, педагогічна майстерність - сукупність якостей особистості, котрі забезпечують високий рівень самоорганізації професійної діяльності педагога, складовими частинами якої є професійні знання, педагогічна техніка, педагогічні здібності, педагогічна моральність, професійно значущі якості (доброзичливість, об'єктивність, вимогливість, порядність, оптимізм, самоконтроль) і зовнішня культура. Всі ці компоненти створюють передумови для перетворення педагогічної діяльності на мистецтво, що є тривалим і складним процесом [17, с. 57-58].

На нашу думку, педагогічна майстерність - це володіння системою педагогічних і психолого-педагогічних знань, умінь і навичок із організації педагогічного процесу та його ефективного проведення. Вона передбачає також володіння педагогічною технікою (технікою використання мовних і немовних засобів, педагогічних дій і прийомів педагогічного спостереження, аналізу, впливу, встановлення контакту); педагогічним тактом; методичною майстерністю; творчими педагогічними вміннями та має у своїй основі педагогічний досвід.

На всіх етапах розвитку вищої школи процес формування педагогічної майстерності був і залишається актуальним, і від нього залежить рівень викладання дисциплін і підготовки здобувачів, у т. ч. дошкільної освіти. Саме викладання психолого-педагогічних дисциплін, що входять до циклу професійної підготовки, виступає як одна з умов успішності формування професійного самовизначення здобувачів дошкільної освіти, зокрема їі когнітивно-гностичного компоненту.

Когнітивно-гностичний компонент об'єднує сукупність знань, отриманих у процесі оволодіння професією у ЗВО і є результатом пізнавальної діяльності, спрямованої на освоєння сутності та специфіки педагогічної діяльності в усьому різноманітті їі проявів в умовах сучасної освіти. Зокрема, критеріями когнітивно-гностичного компоненту виступають: сукупність знань про сутність діяльності педагога-вихователя, про вимоги до рівня його загальнокультурної, психолого-педагогічної та загальнометодичної підготовки, уявлення про свої професійно значущі якості (здібності, індивідуальні особливості, загальнотрудові, спеціальні, комунікативні, творчі уміння), бачення професійних перспектив.

Процес викладання здобувачам психолого-педагогічних дисциплін визначає формування насамперед педагогічної спрямованості майбутніх педагогів-вихователів. Знання, отримані під час вивчення цих дисциплін, виступають як фундамент для дисциплін предметної підготовки, оскільки знання у сфері теорії та методик виховання грунтуються на основних положеннях педагогіки та психології. Таким чином, викладання психолого-педагогічних дисциплін у магістрів сприяє формуванню комплексу знань, умінь, навичок, необхідних для розробки та проведення всіх видів і форм організації просвітницької діяльності у галузі дошкільної освіти на основі методів, засобів та інноваційних педагогічних технологій навчання.

Інтеграція дисциплін циклу професійної підготовки, у т. ч. психолого-педагогічних, забезпечує процеси наступності, послідовності та системності у формуванні когнітивно-гностичного компоненту професійного самовизначення здобувачів педагогічного ЗВО. У ході інтеграційного викладання психолого-педагогічних дисциплін з урахуванням індивідуально-психологічних особливостей особистості здобувача йде цілеспрямований процес поглиблення і зміцнення його знань про сутність діяльності педагога-вихователя.

Так, із метою професійного самовизначення здобувачів підготовки компетентних, професійно мобільних фахівців закладів дошкільної освіти необхідні педагогічні кадри, котрі володіють високим рівнем педагогічної майстерності. У цьому контексті важливе місце займає партнерська взаємодія з учасниками освітнього процесу, яка включає компетентність педагогічного партнерства, психологічну й емоційно-етичну компетентність. Тому аналіз наукової літератури щодо діяльності педагога дає підстави виділити чотири відносно самостійні, але взаємопов'язані блоки педагогічної майстерності викладання психолого-педагогічних дисциплін (рис. 1). Усі ці блоки педагогічної майстерності безперервно пов'язані між собою і лише умовно розділені, для поняття рівня підготовленості педагогічного працівника та шляхів формування його майстерності.

Формування педагогічної майстерності викладання психолого-педагогічних дисциплін передбачає постійне вдосконалення наукового змісту і методики проведення навчальних занять. Будучи синтезом теоретичних знань і високорозвинених практичних умінь, майстерність педагога затверджується через творчість і втілюється у ній.

3 погляду М. М. Солдатенка, для оволодіння педагогічною майстерністю необхідні: систематична підготовка до кожного навчального заняття; постійна робота 3 новинками педагогічної літератури, витяг із них нового, що вимагає практичної перевірки та застосування; вивчення досвіду колег і запозичення усього найкращого, корисного, дійсно необхідного; відмова від стереотипів у педагогічній діяльності; оволодіння індивідуальними прийомами техніки особистої роботи: організацією продуктивної педагогічної праці, постановкою голосу, виробленням мови (граматичної правильності, дикції, інтонації, сили звуку і т. п.); саморегуляцією фізичного і психічного стану [15]. 


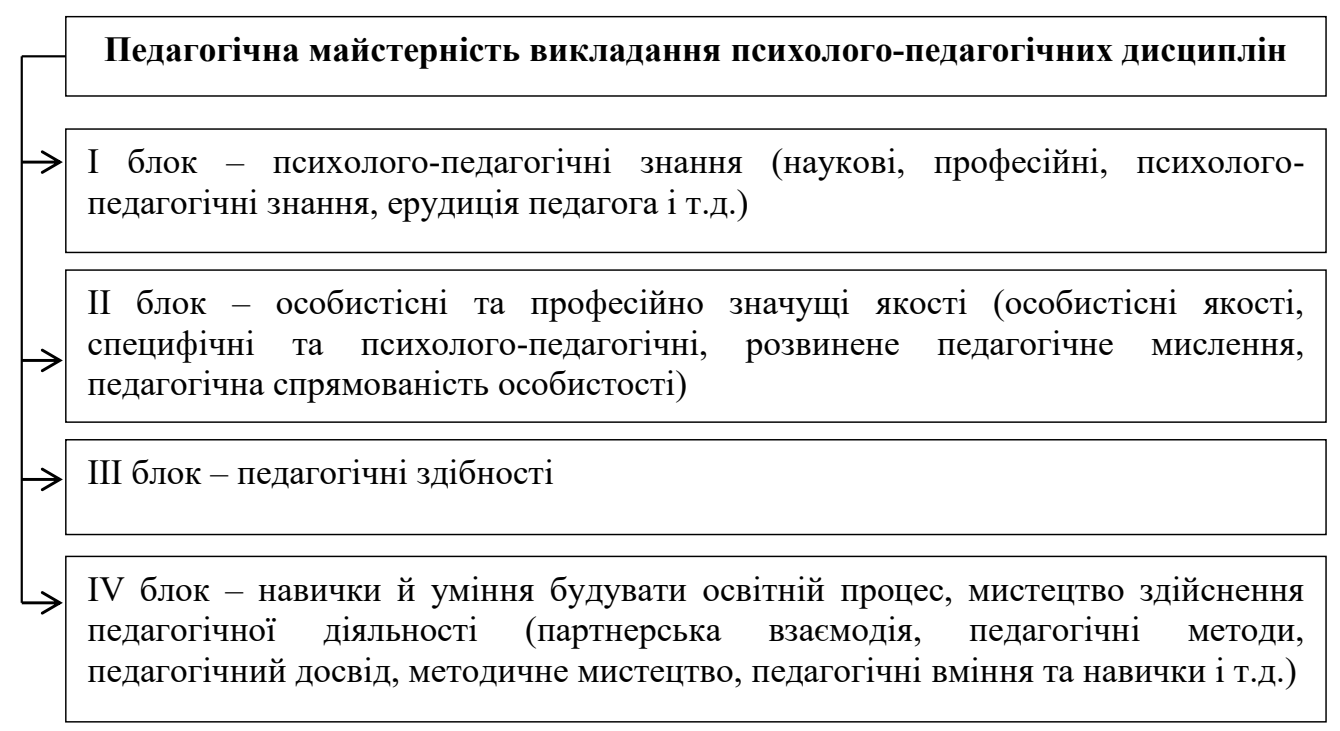

Рис. 1. Педагогічна майстерність викладання психолого-педагогічних дисциплін

Джерело: складено автором на основі [2; 6]

Опанувати секрети педагогічної майстерності можна лише за систематичної та творчої праці, засвоєння об'єктивних закономірностей навчання і виховання, основних педагогічних ідей і принципів, постійного підвищення кваліфікації. Вирішальне значення мають самоосвіта і самовиховання. Тому, на нашу думку, педагогічну майстерність можна визначити як сукупність особливостей діяльності викладача, що робить ефективним процес навчання, виховання. Такими особливостями виступають методи та прийоми, які використовує педагог. Позитивний результат вони дадуть, якщо педагог вміє ними користуватися за призначенням.

Досвід роботи передових ЗВО у сфері підготовки майбутніх фахівців дошкільної освіти стверджує необхідність виділити у структурі педагогічної майстерності викладання психолого-педагогічних дисциплін такі взаємопов'язані елементи: гуманістичну спрямованість; професійні знання; базові педагогічні здібності; педагогічну техніку.

Досліджуючи складові частини педагогічної майстерності, науковці О. Малнацька [8], Н. Мирончук [8], О. Обривкіна [11] сходяться на думці, що ії структура включає у себе професійні знання викладача, яскраво виражену педагогічну спрямованість його особистості, розвинені педагогічні здібності, які грунтуються на професійну придатність, відточену педагогічну техніку.

На думку деяких вітчизняних педагогів (таких як Л. І. Мохнар [9], С. Ф. Поважний [12], О. І. Журавльова [12], О. І. Філіппов [12]), психологічний компонент у структурі професійної майстерності представлений великими знаннями із предмету, глибокими знаннями психології та педагогіки, що є найважливішою умовою ефективної організації освітнього процесу, інтенсивного і якісного розвитку складних умінь і навичок спілкування зі здобувачами, виховного впливу на них. Системоутворюючим компонентом педагогічної майстерності науковці визначають професійну спрямованість особистості викладача, виділяючи такі найбільш значущі їі характеристики, як: 1) ставлення до педагогічної професії як до життєвого покликання; 2) усвідомлення шляхетності та суспільної значимості педагогічної діяльності; 3) сформованість педагогічного мислення, гуманістичних особистісних властивостей і якостей педагога; 4) гуманна педагогічна позиція (I. А. Зязюн, Л. В. Крамущенко, І. Ф. Кривонос) [6].

Специфіка педагогічних здібностей як структурного компоненту професійної майстерності педагога полягає у їх різноманітті, в інтенсивності та якості формування. У працях педагогів і психологів відзначаються як найбільш затребувані сучасною соціокультурною ситуацією саме комунікативні та креативні здібності, здатність до рефлексії, емпатії та проєктування своєї професійної діяльності (Ю. Ю. Бойко-Бузиль, С. Л. Горбенко, О. А. Дубасенюк, О. С. Антонова) [3; 4].

Враховуючи вищезазначене, процес формування педагогічної майстерності викладачів психолого-педагогічних дисциплін умовно можна розділити на три основні періоди.

Перший період - період становлення викладачів-початківців - це той час, упродовж якого вони повинні освоїти курси психолого-педагогічних дисциплін, які викладають, набути практичних навичок, необхідних для самостійної організації навчальної, методичної та виховної роботи. Основу професійної підготовки викладачів має становити оволодіння передовими методами навчання, які не суперечать традиційній системі, але дозволяють удосконалювати останню для створення виховного і навчального середовища ЗВО, що відповідає сучасним вимогам до викладання психолого-педагогічних дисциплін майбутнім фахівцям дошкільної освіти. 
Другий період - удосконалення педагогічної майстерності у проиесі набуття досвіду. Впродовж вказаного періоду відбувається безперервний розвиток педагогічних здібностей, педагогічного такту. Говорячи про другий період формування педагогічної майстерності викладача, необхідно зазначити, що він триває безперервно у процесі всієї подальшої діяльності, а найважливішими напрямками формування педагогічної майстерності викладача $\epsilon$, по-перше, систематичне, планомірне вдосконалення теоретичних і практичних знань; по-друге, підвищення рівня викладання. Перше завдання вирішується насамперед шляхом активної участі викладачів у науково-дослідній діяльності ЗВО, а також у процесі самостійної роботи.

Формування майстерності педагога, підвищення наукового рівня викладання забезпечується роботою колективу кафедри. Внутрішньокафедральна система підвищення педагогічної майстерності викладачів, котрі здійснюють підготовку здобувачів спеціальності 012 “Дошкільна освіта”, має велику практичну спрямованість, оскільки має за мету вирішення конкретних завдань викладання психолого-педагогічних дисциплін із урахуванням специфіки їх вивчення.

Ця система включає різноманітні форми та методи роботи: взаємне відвідування занять, проведення відкритих занять, обмін досвідом методичної роботи, систематичний контроль за ступенем підготовленості викладача до чергових занять і т. д. На кафедрах періодично проводяться співбесіди, готуються наукові повідомлення, обговорюються реферати із проблем конкретних наук. Беззаперечну користь приносять також огляди статей науково-теоретичних журналів, обговорення анотацій нових книг і досліджень, участь викладачів у роботі наукових конференцій і проведенні педагогічних читань. На загальнокафедральних засіданнях регулярно обговорюються лекції з особливо важливих тем навчального плану. До рецензування цих лекцій залучаються усі педагоги. Молоді викладачі, виступаючи на обговореннях, мають можливість перевірити правильність своїх поглядів на зміст і методичну побудову лекції, зіставити їх із думкою досвідчених педагогів. Також формуванню педагогічної майстерності сприяють: психотехнології, діалогічні лекції, діагностуючі практикуми, рефлексивні семінари, тренінги, семінари-практикуми; рольові ігри, дискусії, дидактичні ігри, навчання як дослідження, метод проєктів, “мозковий штурм”, евристичні питання.

Третій період - педагогічне новаторство, коли викладач вносить в освітній процес принципово нові ідеї, розробляє нові методичні системи та створює нові дидактичні методи викладання психолого-педагогічних дисциплін. Методична система викладання психолого-педагогічних дисциплін включає цілі, зміст, методи, організаційні форми та засоби навчання. Вона складається із трьох підсистем: цільової (цілі та завдання, принципи функціонування та функції методичної системи; цільовий компонент має узгоджуватися та переслідувати головну мету: формування психолого-педагогічної компетентності майбутніх фахівців дошкільної освіти, яка сприятиме становленню їх як професіоналів); змістовної (повинна узгоджуватися із цілями та завданнями функціонування методичної системи, а іiі зміст має бути регламентованим нормативними документами щодо освітнього процесу та вимог до майбутніх педагогів-вихователів); процесуально-організаційної (повинна включати найбільш оптимальні форми, методи та засоби проведення занять із психолого-педагогічних дисциплін для досягнення найбільш бажаного результату щодо формування психолого-педагогічної компетентності майбутніх фахівців дошкільної освіти).

Сучасними дидактичними методами викладання психолого-педагогічних дисциплін здобувачам дошкільної освіти виступають: професійне проєктування; ступеневе проєктування; метод професійної комунікації; “золотої середини”; рольової гармонізації; змінюючої тактики; професійної самоорганізації; поглиблення професійно-педагогічних зв'язків; професійного самоконтролю; професійної саморегуляції [3; 4].

Нині у теорії та практиці вищої педагогічної освіти йде пошук інтерактивних методів навчання, за допомогою яких можливе подолання недоліків традиційної організації навчального процесу як індивідуально-спільної діяльності здобувачів. Досвід викладання психологічних і педагогічних дисциплін для здобувачів дошкільної освіти підтверджує необхідність використання механізму реалізації інноваційної освітньої діяльності на основі інтерактивних методів навчання з метою вирішення зазначених вище проблемних завдань підготовки фахівця.

Інтерактивні методи викладання - це сукупність прийомів і засобів, за яких засвоєння матеріалу, його теоретичне і практичне опрацювання організовується у процесі безпосередньої взаємодії здобувачів один з одним. До інтерактивних методів належать: полілог, навчально-педагогічний тренінг, імітаційно-рольове моделювання, педагогічна майстерня тощо.

Метод полілогу передбачає здійснення попередньої самодіагностики здобувачами свого рівня компетентності щодо вирішення проблемного навчального завдання. Результати самодіагностики рівня відповідної компетентності конфіденційно надаються викладачу, котрий організовує групове обговорення на різних етапах заняття як процес послідовного залучення здобувачів до процесу дискусії залежно від рівня їх компетентності. Цей прийом організації навчальної пізнавальної активності здобувачів дозволяє максимально реалізуватися як менш компетентним, так і найбільш компетентним студентам, оскільки останні включаються у дискусію тільки після виступу менш підготовлених “колег”.

Навчально-педагогічний тренінг покращує ефективність засвоєння матеріалу, у процесі якого приділяється більше уваги питанням індивідуального й особистісного творчого розвитку та професійного становлення; створює психологічно-комфортні умови, за яких здобувач дошкільної освіти може максимально реалізувати свій інтелектуальний потенціал і відчути себе успішним і самостійним в освоєнні певних 3нань [20, с. 367]. 
Одним із методів, що відповідає вимогам часу, можна назвати метод педагогічної майстерні. Звісно ж, положення педагогічної майстерні, розроблені й описані I. А. Мухіною, дозволяють ефективно реалізовувати навчальний і творчий потенціал кожного здобувача незалежно від його стартових предметних результатів. Ідея діалогу в усіх його аспектах, покладена в основу майстерні, дає можливість презентації результатів власної діяльності й “обміну думками, творчими знахідками” у роботі в парах або групах [10].

Залежно від предметної спрямованості педагогічна майстерня може мати різні форми втілення. Головне полягає у дотриманні основного принципу - створення атмосфери взаємної творчості за активізації та реалізації особистісного освітнього і творчого потенціалу здобувачів. Розвиток педагогічної майстерності педагога неможливо уявити без його кропіткої щоденної самостійної роботи 3 додаткового вивчення регламентуючих документів, організації освітньої, методичної та наукової роботи на кафедрі, поглибленню знань із психолого-педагогічних дисциплін.

Останнім часом показав велику ефективність “інститут” наставництва, коли за педагогічними працівниками-початківцям закріплюється найбільш досвідчений педагог. Це дозволяє передавати накопичений досвід, надавати допомогу у підготовці та проведенні занять, проводити взаємне відвідування, аналіз і контроль.

Головною умовою досягнення високих результатів педагогічної майстерності є особисте бажання викладача домагатися свого професіоналізму. Для цього він повинен постійно критично себе оцінювати, робити професійні висновки. Даними для цього можуть служити результати контролю якості проведення навчальних занять, рівень проведення відкритих і пробних занять, звітність про свою роботу з удосконалення педагогічної майстерності, як в усній, так і в письмовій формі, результати зворотного зв’язку здобувачів (врахування думки здобувачів про якість педагогічної діяльності).

Оволодіння педагогічною технікою дозволяє швидко і точно знайти потрібне слово, інтонацію, погляд, жест, а також зберігати спокій і здатність до ясного мислення, аналізу в найгостріших і несподіваних педагогічних ситуаціях, призводить до зростання задоволеності педагога своєю професійною діяльністю. Індивідуальна педагогічна техніка істотно залежить від віку, статі, темпераменту, характеру педагога, стану здоров’я, анатомо-фізіологічних особливостей. Основою педагогічної техніки $є$ професійні знання.

Висновки. Таким чином, реалізація будь-якого інноваційного проекту суспільного розвитку значуща не лише самим процесом, управлінням і забезпеченням умов його реалізації, а також і ефективним використанням отриманих результатів в освітньому процесі (у конкретному випадку - у роботі зі здобувачами дошкільної освіти). Для успішного вирішення цього завдання педагогічним працівникам необхідно не лише володіти професійними знаннями й ерудицією в конкретних галузях знань (психології та педагогіці), але і застосовувати сучасні інтерактивні методи з метою передачі цих знань здобувачам. Педагога, котрий володіє високим рівнем педагогічної майстерності, можна виявити за такими критеріями, як: 1) гармонійно розвинена, внутрішньо багата особистість, яка прагне до духовної, професійної, загальнокультурної та фізичної досконалості; 2) вміє відбирати найбільш ефективні інтерактивні методи, прийоми, засоби та технології навчання і виховання для реалізації педагогічних завдань; 3) володіє високим ступенем професійної компетентності; 4) вміє організувати рефлексивну діяльність, спрямовану на самовдосконалення.

Отже, формування педагогічної майстерності викладання психолого-педагогічних дисциплін необхідно розглядати як основну мету освітнього процесу у закладах вищої освіти.

\section{Використана література:}

1. Барбіна Є. С. Педагогічна майстерність у сучасній парадигмі освіти. Педагогічні науки. 2014. № 64. С. 181-185.

2. Бобер І. М. Від інноваційного змісту і технологій освіти до інноваційного прогресу. Від інновачійного змісту і технологій освіти до інноващійного прогресу : збірник наукових праць Всеукраїнської науково-практичної конференції. Кременчук : ПП Щербатих, 2013. С. 10-12.

3. Бойко-Бузиль Ю. Ю., Горбенко С. Л. Методика викладання психології у вищій школі : навчальний посібник. Київ : Атіка, 2012. $272 \mathrm{c}$

4. Дубасенюк О. А., Антонова О. Є. Методика викладання педагогіки : навчальний посібник. Житомир : Вид-во ЖДУ ім. І. Франка, 2012. 375 с.

5. Зязюн І. А. Педагогічна майстерність : підручник. Київ : “Вища школа”, 2004. 422 с.

6. Зязюн І. А., Крамущенко Л. В., Кривонос І. Ф. та ін. Педагогічна майстерність : підручник. Київ : Вища освіта, 2009. $422 \mathrm{c}$.

7. Локшина О. Забезпечення якості вищої освіти в умовах європеїзації України. Неперервна професійна освіта: теорія $i$ практика. 2018. Вип. 3-4. С. 127-132.

8. Малнацька О., Мирончук Н. Педагогічна майстерність викладача ВНЗ. Модернізація вищої освіти в Україні та за кордоном : збірник наукових праць. 2014. С. 61-64.

9. Мохнар Л. І. Інноваційні педагогічні технології як компонента педагогічної майстерності викладача вищого навчального закладу. Питання педагогіки. Вісник Національного університету оборони Украӥни. 2014. № 3 (40). С. 117-122.

10. Мухина И. А. Что такое педагогическая мастерская. URL: https ://slovesnik. org/kopilka/stati/chto-takoe-pedagogicheskayamasterskaya.html. (дата обращения: 10.10.2021).

11. Обривкіна О. М. Сучасні форми методичної роботи з підвищення педагогічної майстерності викладачів в університеті. Науковий вісник Національного університету біоресурсів і природокористування Украӥни. 2010. Ч. 2. С. 111-119.

12. Поважний С. Ф., Журавльова О. І., Філіппов О. І. Дидактичні аспекти педагогіки вищої школи : навчально-методичний посібник. Донецьк : ДонДУУ, 2008. 286 с. 
13. Пометун О. І. Енциклопедія інтерактивного навчання. Дніпро : Середняк Т. К., 2019.

14. Про затвердження стандарту вищої освіти за спеціальністю 012 “Дошкільна освіта" для другого (магістерського) рівня вищої освіти : Наказ МОН № 572 від 29 квітня 2020 p. URL: https://mon.gov.ua/storage/app/media/vyshcha/ standarty/2020/05/2020-zatverd-standart-012-m.pdf (дата звернення: 07.10.2021).

15. Солдатенко М. М. Саморозвиток педагогічної майстерності викладача в умовах інформаційно-технологічного суспільства : посібник. Київ : Інститут педагогічної освіти і освіти дорослих НАПН України, 2015. 153 с.

16. Туркот Т. І. Педагогіка вищої школи : навчальний посібник. Київ : Кондор, 2011. 628 с.

17. Фіцула М. М. Педагогіка вищої школи : навчальний посібник. Київ : “Академвидав”, 2006. 352 с.

18. Харківська А. І. Розвиток комунікативної культури майбутніх вихователів закладів дошкільної освіти : навчальний посібник. Харків, 2020. 444 с.

19. Шолох О. А. Теоретичні аспекти розвитку педагогічної майстерності викладачів вищої школи. Вісник Національного університету “Чернігівський колегіум" імені Т. Г. Шевченка.2019. № 1 (157). С. 245-251.

20. Якимчикас $\mathcal{\Theta}$. В. Навчально-педагогічні тренінги як засіб формування компетентності педагогічного партнерства. Грааль науки. 2021. № 1. С. 365-370.

\section{References:}

1. Barbina Ye. S. (2014) Pedahohichna maisternist u suchasnii paradyhmi osvity [Pedagogical skills in the modern paradigm of education]. Pedahohichni nauky: zbirnyk naukovykh prats, 64, 181-185 [in Ukrainian].

2. Bober I.M. (2013) Vid innovatsiinoho zmistu i tekhnolohii osvity do innovatsiinoho prohresu [From innovative content and educational technologies to innovative progress]. Vid innovatsiinoho zmistu i tekhnolohii osvity do innovatsiinoho prohresu: $\mathrm{zb}$. nauk. pr. Vseukrainskoi naukovo-praktychnoi konferentsii. Kremenchuk : PP Shcherbatykh, 10-12 [in Ukrainian].

3. Boiko-Buzyl Yu. Yu., Horbenko S. L. (2012) Metodyka vykladannia psykholohii u vyshchii shkoli [Methods of teaching psychology in high school]. Kyiv : Atika[in Ukrainian].

4. Dubaseniuk O. A., Antonova O. Ie. (2012) Metodyka vykladannia pedahohiky [Methods of teaching pedagogy]. Zhytomyr: Vyd-vo ZhDU im. I. Franka [in Ukrainian].

5. Ziaziun I. A. (2004) Pedahohichna maisternist [Pedagogical skills]. Kyiv : "Vyshcha shkola" [in Ukrainian].

6. Ziaziun I. A., Kramushchenko L. V., Kryvonos I. F. (2009) Pedahohichna maisternist [Pedagogical skills]. Kyiv : Vyshcha osvita [in Ukrainian].

7. Lokshyna O. (2018) Zabezpechennia yakosti vyshchoi osvity v umovakh yevropeizatsii Ukrainy [Ensuring the quality of higher education in the context of Europeanization of Ukraine]. Neperervna profesiina osvita: teoriia i praktyka [Continuing professional education: theory and practice], 3-4, 127-132 [in Ukrainian].

8. Malnatska O., Myronchuk N. (2014) Pedahohichna maisternist vykladacha VNZ [Pedagogical skills of university teachers]. Modernizatsiia vyshchoi osvity v Ukraini ta za kordonom: zbirnyk naukovykh prats, 61-64 [in Ukrainian].

9. Mokhnar L. I. (2014). Innovatsiini pedahohichni tekhnolohii yak komponenta pedahohichnoi maisternosti vykladacha vyshchoho navchalnoho zakladu [Innovative pedagogical technologies as a component of pedagogical skills of a higher education teacher]. Pytannia pedahohiky. Visnyk Natsionalnoho universytetu oborony Ukrainy [Questions of pedagogy. Bulletin of the National University of Defense of Ukraine], 3 (40), 117-122 [in Ukrainian].

10. Mukhyna Y. A. Chto takoe pedahohycheskaia masterskaia [What is a pedagogical workshop]. Reteved from: https://slovesnik. org/kopilka/ stati/chto-takoe-pedagogi cheskaya-masterskaya.html [in Russian].

11. Obryvkina O. M. (2010) Suchasni formy metodychnoi roboty z pidvyshchennia pedahohichnoi maisternosti vykladachiv $v$ universyteti [Modern forms of methodical work to improve the pedagogical skills of teachers at the university]. Naukovyi visnyk Natsionalnoho universytetu bioresursiv i pryrodokorystuvannia Ukrainy [Scientific Bulletin of the National University of Life and Environmental Sciences of Ukraine], 2, 111-119 [in Ukrainian].

12. Povazhnyi S. F., Zhuravlova O. I., Filippov O. I. (2008) Dydaktychni aspekty pedahohiky vyshchoi shkoly [Didactic aspects of higher school pedagogy]. Donetsk : DonDUU [in Ukrainian].

13. Pometun O. I. (2019) Entsyklopediia interaktyvnoho navchannia [Encyclopedia of interactive learning]. Dnipro: Seredniak T. K. [in Ukrainian].

14. Pro zatverdzhennia standartu vyshchoi osvity za spetsialnistiu 012 "Doshkilna osvita" dlia druhoho (mahisterskoho) rivnia vyshchoi osvity [On approval of the standard of higher education in the specialty 012 "Preschool education" for the second (master's) level of higher education]: Nakaz MON № 572 (2020, April 04). Reteved from: https://mon.gov.ua/storage/app/media/ vyshcha/standarty/2020/05/2020-zatverd-standart-012-m.pdf [in Ukrainian].

15. Soldatenko M. M. (2015) Samorozvytok pedahohichnoi maisternosti vykladacha v umovakh informatsiino-tekhnolohichnoho suspilstva [Self-development of pedagogical skill of the teacher in the conditions of information-technological society]. Kyiv: Instytut pedahohichnoi osvity i osvity doroslykh NAPN Ukrainy [in Ukrainian].

16. Turkot T. I. (2011) Pedahohika vyshchoi shkoly [Higher school pedagogy] Kyiv : Kondor [in Ukrainian].

17. Fitsula M. M. (2006) Pedahohika vyshchoi shkoly [Higher school pedagogy]. Kyiv : "Akademvydav" [in Ukrainian].

18. Kharkivska A. I. (2020) Rozvytok komunikatyvnoi kultury maibutnikh vykhovateliv zakladiv doshkilnoi osvity [Development of communicative culture of future educators of preschool institutions]. Kharkiv [in Ukrainian].

19. Sholokh O. A. (2019) Teoretychni aspekty rozvytku pedahohichnoi maisternosti vykladachiv vyshchoi shkoly [Theoretical aspects of the development of pedagogical skills of higher school teachers]. Visnyk Natsionalnoho universytetu "Chernihivskyi kolehium" imeni T. H. Shevchenka [Bulletin of the Taras Shevchenko National University "Chernihiv Collegium"], 1 (157), 245-251 [in Ukrainian].

20. Iakymchykas Ye. V. (2021) Navchalno-pedahohichni treninhy yak zasib formuvannia kompetentnosti pedahohichnoho partnerstva [Educational and pedagogical trainings as a means of forming the competence of pedagogical partnership]. Hraal nauky [The Grail of Science], 1, 365-370 [in Ukrainian]. 
Yatsenko V. V. Pedagogical skills in teaching psychological and pedagogical disciplines to educators at the present stage

The article highlights the essence of the concept of "pedagogical skills". Peculiarities of teaching psychological and pedagogical disciplines in the context of formation of professional self-determination of applicants of specialty 012 "Preschool education", in particular, its cognitive-gnostic component are determined. It is established that in the course of integration teaching of psychological and pedagogical disciplines taking into account individual psychological features of the applicant's personality there is a purposeful process of deepening and strengthening of his knowledge about essence of activity of the teacher-educator. There are four relatively independent but interconnected blocks of pedagogical skills: psychological and pedagogical knowledge; personal and professionally significant qualities; pedagogical abilities; skills and abilities to build the educational process, the art of teaching. It is noted that the experience of advanced free economic education in the field of training future preschool education specialists allows to distinguish the following interrelated elements in the structure of pedagogical skills of teaching psychological and pedagogical disciplines: humanistic orientation, professional knowledge, basic pedagogical abilities, pedagogical techniques. It is pointed out that pedagogical abilities in their essence act as an individual trajectory of development of a pedagogical worker. Three main periods of the process of formation of pedagogical skills are formed: the period of formation of beginning teachers; improvement of pedagogical skills in the process of gaining experience; pedagogical innovation. It is noted that the experience of teaching psychological and pedagogical disciplines for preschoolers confirms the need to use the mechanism of innovative educational activities based on interactive teaching methods to solve problems of training future professionals (polylogist, educational and pedagogical training, simulation-role modeling, pedagogical workshop). The directions of improvement of pedagogical skill of teaching of psychological and pedagogical disciplines to applicants of preschool education are offered: integrity and continuity of preparation and advanced training of pedagogical workers; formation of teachers'stable motivation to improve pedagogical skills; improvement of pedagogical techniques.

Key words: education, teacher, preschoolers, pedagogical skills, partnership, mentoring, interactive teaching methods, pedagogical workshop.

УДК 378.091.3:373.3.011.3-051:37.014.53

DOI https://doi.org/10.31392/NPU-nc.series5.2021.83.50

Севастюк М. С.

\section{ДЕМОКРАТИЗАЦІЯ ОСВІТНЬОГО ПРОЦЕСУ В ПРОФЕСІЙНІЙ ПІДГОТОВЦІ МАЙБУТНЬОГО ВЧИТЕЛЯ ПОЧАТКОВОЇ ШКОЛИ}

У статті висвітлюється питання забезпечення демократизаиії освітнього процесу в професійній підготовиі вчителя початкової школи та визначається його вплив на якість професійної підготовки майбутнього вчителя початкової иколи.

Проведений аналіз літератури з питання дав можливість розглянути демократизацію освіти як складний, багатогранний процес, який містить усі складники системи освіти, зокрема: від управління освітою на рівні держсви, системи освіти та школи до управління спілкуванням та самоорганізацією кожного учасника освітнього процесу.

Демократизація освітнього процесу розглядається як впровадження демократичних засад у спільну діяльність учасників, встановлення «суб 'єкт-суб' єктних» відносин під час навчання. Проявами демократизації освіти у навчальному процесі є розвиток суб'єктності студентів, які виступають активними учасниками професійного становлення та особистісного розвитку, встановлення відносин співпраці та партнерства в освітньому процесі.

Демократизачія освітнього процесу передбачає використання викладачем активних методів навчання, до яких належать інтерактивні вправи, групова робота, досліднищькі, проєктні завдання. Це призводить до зміни місия та ролі викладача - від інформатора, наставника до фасилітатора.

Сприятливі умови створює демократичне освітнє середовище закладу вищої освіти, яке базується на принципах альтернативності, різноманітності, вільного вибору та відповідальності студентів.

Демократизачія освітнього прочесу забезпечує свідоме засвоєння професійних знань через їхн особистісне засвоєння студентами, формування фахових компетентностей через активну практичну діяльність, але насамперед забезпечує розвиток демократичних иінностей особистості, формування у них активної та відповідальної громадянської позииії, щуо є основою становлення конкурентоздатного вчителя початкової школи та підвищення якості професійної підготовки.

Ключові слова: професійна підготовка, демократизачія освіти, демократизація освітнього процесу, демократичні цінності, суб 'єктність, педагогіка партнерства, активні методи навчання, демократичне освітнє середовище.

Зміни, які відбуваються у початковій школі у зв’язку із впровадженням концепції стратегічного розвитку вітчизняної освіти “Нова українська школа", зумовлюють нові підходи до підготовки вмотивованого, компетентного, конкурентоздатного вчителя початкової школи. Змінюється не лише зміст підготовки, в основі якого закладені компетентнісний та інтегрований підходи до оволодіння педагогічною професією, значної перебудови зазнає організація освітнього процесу у вищій школі, яка передусім спрямована на ствердження діяльнісного та персоніфікованого підходів, упровадження демократичних цінностей у професійну освіту, підготовку вчителя, здатного створювати демократичне освітнє середовище у сучасній українській школі. 